\title{
COMPARISON OF PRESERVATIVES EFFICACY OF BENZALKONIUM CHLORIDE, THIMEROSAL AND BENZYL ALCOHOL IN EYE DROP PRODUCTS CONTAINING CHLORAMPHENICOL
}

\author{
SRI AGUNG FITRI KUSUMA ${ }^{1 *}$, MARLINE ABDASSAH ${ }^{2}$, FITASARY MARYATI ${ }^{2}$
}

${ }^{1}$ Department of Biology Pharmacy, Faculty of Pharmacy, Padjadjaran University, Sumedang, West Java, Indonesia 45363, 2Departement of Pharmaceutics, Faculty of Pharmacy, Padjadjaran University, Sumedang, West Java, Indonesia 45363

Email: s.a.f.kusuma@unpad.ac.id

Received: 30 Mar 2020, Revised and Accepted: 02 May 2020

\section{ABSTRACT}

Objective: The aim of this study was to compare the preservative efficacy of benzalkonium chloride, thimerosal and benzyl alcohol in eye drops formulation containing chloramphenicol as the active agents for producing the sterile and effective eye drops.

Methods: The efficacy of preservatives was assayed by evaluating the physical appearance, $\mathrm{pH}$ stability, sterility and the antibacterial effectivity of the formulated eye drops. Each of $0.5 \%$ chloramphenicol was formulated with different preservatives of benzalkonium chloride, thimerosal and benzyl alcohol at its recommended concentration, $0.01 \% ; 0.01 \%$ and $1 \%$, respectively. The in vitro stability was examined periodically for the eye drops formulation stored at room temperature during the 28-day period. The effectiveness of the antibacterial effect of chloramphenicol in eye drops was assayed by using the agar diffusion method against Escherichia coli and evaluated for the diameter of inhibition zones.

Result: The clarity of the eye drops formula produced clear solutions. The eye drops formula exhibited relatively stabile on pH. All the formulated eye drops were sterile during the storage time. The appropriate of the sterilization method was thought to contribute to the sterility of eye drops which did not contain preservatives. In addition, it was assumed that the pre-reaction of chloramphenicol in inhibiting the contaminants in the eye drop may occur during the storage time. This hypothesis was confirmed by the inhibitory diameter stability produced by the eye drop formulas containing preservatives compared to that of not. The decrease in inhibition diameter occurred during the storage period ( $28 \mathrm{~d})$ of each formula was as follows: F0 (51.58\%), F1 (35.76\%), F2 (31.86\%), and F3 (35.35\%). The best stability based on the antibacterial activity of the chloramphenicol eye drops was produced by F2 which used $0.01 \%$ thimerosal as its preservative. The differences in inhibition diameter were significantly influenced by the presence and the type of preservatives.

Conclusion: $0.01 \%$ thimerosal indicated the best improvement on the efficacy of $0.5 \%$ chloramphenicol eye drop.

Keywords: Eye drops, Chloramphenicol, Thimerosal, Benzalkonium chloride, Benzyl alcohol

(C) 2020 The Authors. Published by Innovare Academic Sciences Pvt Ltd. This is an open access article under the CC BY license (http://creativecommons.org/licenses/by/4.0/) DOI: http://dx.doi.org/10.22159/ijap.2020v12i4.37686. Journal homepage: https://innovareacademics.in/journals/index.php/ijap

\section{INTRODUCTION}

Bacterial conjunctivitis is a highly contagious eye infection signed with red eye, tearing, and discharge from one or both eyes that more common in infants and children than in adults [1]. The sources of eye contaminants can be originated from various sources of environmental contamination, both directly infect the eye through the wear of contact lens or from the contaminated eye drops in the multidose form [2, 3]. The main causative bacteria are Streptococcus pneumoniae, Haemophilus influenza, and Staphylococcus aureus [4, 5]. Among those bacteria, $S$. aureus is commonly found in adults and the elderly than in children cases. These bacteria can spread through contact with patients, such as eye contact, hand, fomite, and respiratory droplets [6]. Direct exposure of bacteria onto the conjunctiva generates to infectious conjunctivitis [2]. Subsequent infections caused by the bacterial contamination can pose a serious threat to human health. Bacterial conjunctivitis in individuals which wear contact lens have a risk to be subsequent as bacterial keratitis, an infection which is more severe than conjunctivitis $[4,5]$. In addition, the contamination can be sourced from the eye drop product, which reported mostly from the caps (45.9\%), droppers (41.0\%) and residual contents (13.1\%) [7].

Studies have revealed that approximately 50 percent of infectious conjunctivitis in pediatric are related to bacteria, thus physicians administer antibiotics in the majority of these cases $[8,9]$. Actually, acute bacterial conjunctivitis is often a self-limiting disease, but the use of antibiotics can significantly increase the level of clinical and microbiological improvement [10]. The most frequently treatment to treat bacterial conjunctivitis is a topical application such as eye drops or eye ointment because it is easy to use, can provide high drug concentrations, and evade systemic absorption [11]. Chloramphenicol is the gold standard and the most common active drug prescribed in the topical application to treat bacterial conjunctivitis $[12,13]$. Chloramphenicol significantly inhibited the growth of eye pathogens up to $94 \%$ and its efficacy in ocular infections was $91-93 \%[14,15]$. Meanwhile, traditional medicines are not recommended for eye treatment because they are reportedly involved as a major risk factor in the current corneal ulceration epidemic in developing countries [16]. But the use of antibiotics in eye drops is not always safe, especially in multidose eye drops. Unfortunately, ocular solutions used for therapeutic purposes were reported to be contaminated with pathogens and caused serious eye infections such as endophthalmitis and keratitis [17]. The contamination rate of multidose eye drops was reported to be higher in bottles that have been opened for two weeks than that of unopened. Most of the samples were contaminated by coagulasenegative Staphylococci, while nine other samples were contaminated by different microorganisms. The role of benzalkonium chloride as the preservative in these eye drops preparations was reported to be ineffective, because it still yielded a fairly high level of contamination (34.4\%) [18].

The primary objective of preservatives addition into eye drops products is to inhibit the microbial growth, which can cause active drug degradation $[19,20]$. Thus, the product sterility is maintained during use. In addition to its effectiveness, an important thing to be considered in the selection of preservatives is the cytotoxic effect that can occur in the long term-therapy, especially in eye drops using multiple preserved drugs. As reported in another study, the stabilized oxychloro complex can damage the rabbit corneal epithelial cells and benzalkonium chloride showed cytotoxic effects in cell culture, both in animal or human research [21]. Another preservative that has been reported to be most effective in killing $99.6 \%$ of the microorganism present was benzyl alcohol, but the toxicity of benzyl alcohol in human retinal pigment epithelial (RPE) 
cells had been reported [22, 23]. The United States Centers for Disease Control and Prevention declares that thimerosal is a safe preservative and disclaimed the statement that thimerosalcontaining vaccine preservative was related to autism cases in children [19]. Therefore, it is important to determine the type of effective preservative in eye drops formulations containing chloramphenicol antibiotics to ensure the antimicrobial activity against the contaminants and to prevent the active drug from structure degradation.

\section{MATERIALS AND METHODS}

\section{Materials}

Escherichia coli ATCC 25922, Bacillus subtillis ATCC 6633 and Candida albicans ATCC 10231 were used in this study and obtained from the Laboratory of Microbiology, Faculty of Pharmacy, Padjajaran University, Indonesia. The bacterial growth medium used were Mueller Hinton Broth/MHB (Oxoid), Mueller Hinton Agar/MHA (Oxoid), Soybean-Casein Digest Broth/SCDB (Pronadisa) and Fluid Thioglicolate Medium/FTM (Oxoid). The chemicals used include chloramphenicol (PT. Cendo), boric acid (Merck), sodium tetraborate (Merck), redistillata water (PT. Ikapharmindo Indonesia), and 70\% alcohol (PT. Brataco Indonesia).

\section{Formulation of $0.5 \%$ chloramphenicol eye drops}

Eye drops consisted of four formulations with the addition of different preservatives, including benzalkonium chloride, thimerosal, and benzyl alcohol. The formulas were a negative control formula (without preservative), presented in table 1 . The eye drop formulation consisted of a positive control formula (F1) with a $0.01 \%$ preservative concentration and the remains formulas were tested formula which formulated with the addition of $0.01 \%$ benzalkonium chloride (F1), $0.01 \%$ thimerosal (F2), and $1 \%$ benzyl alcohol (F3).

Table 1: $0.5 \%$ Chloramphenicol eye drop formula

\begin{tabular}{|c|c|c|c|c|}
\hline Composition & F0 (\%) & F1 (\%) & F2 (\%) & F3 (\%) \\
\hline Chloramphenicol & 0.50 & 0.50 & 0.50 & 0.50 \\
\hline Boric acid & 1.50 & 1.50 & 1.50 & 1.50 \\
\hline Sodium tetraborate & 0.30 & 0.30 & 0.30 & 0.30 \\
\hline Benzalkonium chloride & 0.00 & 0.01 & 0.00 & 0.00 \\
\hline Thimerosal & 0.00 & 0.00 & 0.01 & 0.00 \\
\hline Benzyl alcohol & 0.00 & 0.00 & 0.00 & 1.00 \\
\hline Sterile aqua pro injection (API) & Ad 100 & Ad 100 & Ad 100 & Ad 100 \\
\hline
\end{tabular}

The chloramphenicol, sodium tetraborate and boric acid were mixed, then dissolved in a part of the sterile aqua pro injection. After dissolving, the preservative solution was added and the remaining sterile API was mixed and homogenized. Then the $\mathrm{pH}$ of each eye drop solution was measured. The solution was then sterilized using bacterial filter. The sterilized preparations were stored at room temperature and protected from the sunlight. Observations were made on days of $1,3,7,14,21$ and 28.

\section{Evaluation}

\section{Clarity}

The clarity and color changes of the eye drops preparation were inspected visually based on the level of turbidity of the product or the presence of floating particles in the eye drops solution.

\section{pH}

$\mathrm{pH}$ of the eye drops solution was measured by a $\mathrm{pH}$ meter.

\section{Sterility test}

A loopful of B. subtilis colony was inoculated in FTM medium and incubated at $30-35{ }^{\circ} \mathrm{C}$ for $18 \mathrm{~h}$. Meanwhile the C. albicans colony used SCDB medium as the growth medium and incubated at 20-25 ${ }^{\circ} \mathrm{C}$ for $72 \mathrm{~h}$. The resulted of microbial incubation was adjusted to the certain turbidity that equivalent to $0.5 \mathrm{Mc}$ Farland $\left(1.5 \times 10^{8} \mathrm{cfu} / \mathrm{ml}\right)$. The microbial suspension, then diluted to $1 \times 10^{7} \mathrm{cfu} / \mathrm{ml}$ [24]. Before the media were used for the sterility test, the fertility test must be conducted to certify that the FTM and SCDB media were free from substances which may inhibit the microbial growth. The growth of $B$. subtilis indicated the fertility of the FTM medium and $C$. albicans growth in the SCDB media as fungal indicator. As the procedure of the fertility test, the inoculated FTM was incubated at $30-35^{\circ} \mathrm{C}$ for 7 $\mathrm{d}$, whereas the SCDB inoculated medium was incubated at $20-25^{\circ} \mathrm{C}$ for $3 \mathrm{~d}$. The turbidity of the bacterial and fungal suspension indicated the bacterial or fungal growth. The sterility of the uninoculated media was evaluated by incubating the media at the same condition as the fertility test [25].

The eye drops preparation was pipetted for $2 \mathrm{ml}$ and each of $1 \mathrm{ml}$ of it was homogenized in FTM and SCD medium, then incubated based on the intended microbial contamination target. To check the presence of bacterial contamination in the aye drop preparation, the tested FTM media were incubated at at $30-35^{\circ} \mathrm{C}$ for no less than 14 d. Meanwhile, the fungal contamination presence can be detected after the tested SCD medium was incubated at a temperature of 20$25{ }^{\circ} \mathrm{C}$ for no less than $7 \mathrm{~d}$. The presences of the contaminants were evaluated by observing the turbidity of the media everyday, compared to control tube containing the uninoculated FTM media or SCD media and positive control containing the inoculated media. FTM media were inoculated with $B$. subtilis, and the SCD media were inoculated with C. albicans, as the positive control [25].

\section{Efficacy test}

A standardized of E. coli ( 0.5 Mac Farland turbidity standard) in a volume of $20 \mu \mathrm{l}$ was inoculated into $20 \mathrm{ml}$ sterile MHA. The media was allowed to solidify, then perforated and filled with a $50 \mu \mathrm{l}$ of each eye drops preparation formulas. The tested media were incubated for $18-24 \mathrm{~h}$ at $37^{\circ} \mathrm{C}$. The presence of inhibition zones was documented and the diameters were measured using a caliper.

\section{Statistical analysis}

The purpose of the statistical analysis in this study was to determine the effect of differences in $0.5 \%$ chloramphenicol eye drops on the antibacterial effectiveness. The data of inhibition diameter for each eye drop preparation was processed by a statistical method using a factorial design, where the effectiveness of these preparations was used as an independent variable [26]. While the variation of preparations was stated as a factor A and storage time as a factor B. The results of the statistical test were then followed by the Newman Keuls test.

\section{RESULTS AND DISCUSSION}

\section{Visual observation}

The clarity and the color of the eye drop preparations was observed to assess the presence of the particles visually using black and white background in suitable lighting. All formulas of chloramphenicol eye drops demonstrated as clear product and no color changes were occurred during the storage period at the room temperature. The results indicated that the chloramphenicol formulated in the eye drops did not undergo a photolysis reaction. This reaction must be considered as reported in another study that chloramphenicol in the form of an aqueous solution can be degraded upon exposure to sunlight [27].

\section{pH evaluation}

The stability of $\mathrm{pH}$ values can be used as a depiction of the eye drops compatibility with eye physiology. $\mathrm{pH}$ compatibility is very 
important to ensure the eye comfort after the eye drops used. The accepted $\mathrm{pH}$ of the eye was reported in different range based on several studies, in the range $\mathrm{pH}$ of 5.5-11.4, and a range of 4-8 [28, 29]. The incompatibility of eye drops $\mathrm{pH}$ in eyes, may irritate the eyes and increase the tear production which may lead to the decrease of the chloramphenicol bioavalaibility as the active agent [28]. It can be concluded that the $\mathrm{pH}$ of the eye drop is an essential parameter to be considered to prevent the unexpected effects. The alter of $\mathrm{pH}$ in eye drops may be considered as the microbial contamination presence in the eye drops preparation. Thus, the further evaluation must be conducted to ensure the sterility of the products. In this study, the $\mathrm{pH}$ of all formulas was decreasing over the period of storage time, from 7.12 down to 7.05 , presented in table 2 and fig. 1. Based on the $\mathrm{pH}$ graph, the sharpest decrease in $\mathrm{pH}$ was shown by the eye drop formula containing benzyl alcohol as its preservative. Whereas the $\mathrm{pH}$ decreasing in the $\mathrm{F} 1$ and $\mathrm{F} 2$ formula containing benzalkonium chloride and thimerosal, respectively, were not significantly different. However, in this study, all $\mathrm{pH}$ formulas of chloramphenicol eye drops still fulfill the recommended eye $\mathrm{pH}$ range.

Table 2: The pH changes of eye drops over storage time

\begin{tabular}{lllll}
\hline days & F0 & F1 & F2 & F3 \\
\hline 1 & $7.11 \pm 0.000$ & $7.12 \pm 0.000$ & $7.12 \pm 0.000$ & $7.11 \pm 0.001$ \\
3 & $7.09 \pm 0.000$ & $7.11 \pm 0.000$ & $7.10 \pm 0.000$ & $7.09 \pm 0.000$ \\
7 & $7.07 \pm 0.000$ & $7.09 \pm 0.001$ & $7.08 \pm 0.000$ & $7.08 \pm 0.000$ \\
14 & $7.06 \pm 0.001$ & $7.07 \pm 0.000$ & $7.06 \pm 0.000$ & $7.06 \pm 0.001$ \\
21 & $7.06 \pm 0.000$ & $7.07 \pm 0.005$ & $7.06 \pm 0.000$ & $7.05 \pm 0.000$ \\
28 & $7.05 \pm 0.002$ & $7.06 \pm 0.005$ & \\
\hline
\end{tabular}

Notes: Each number of experiment replication=3; pH changes $(($ mean \pm SD)

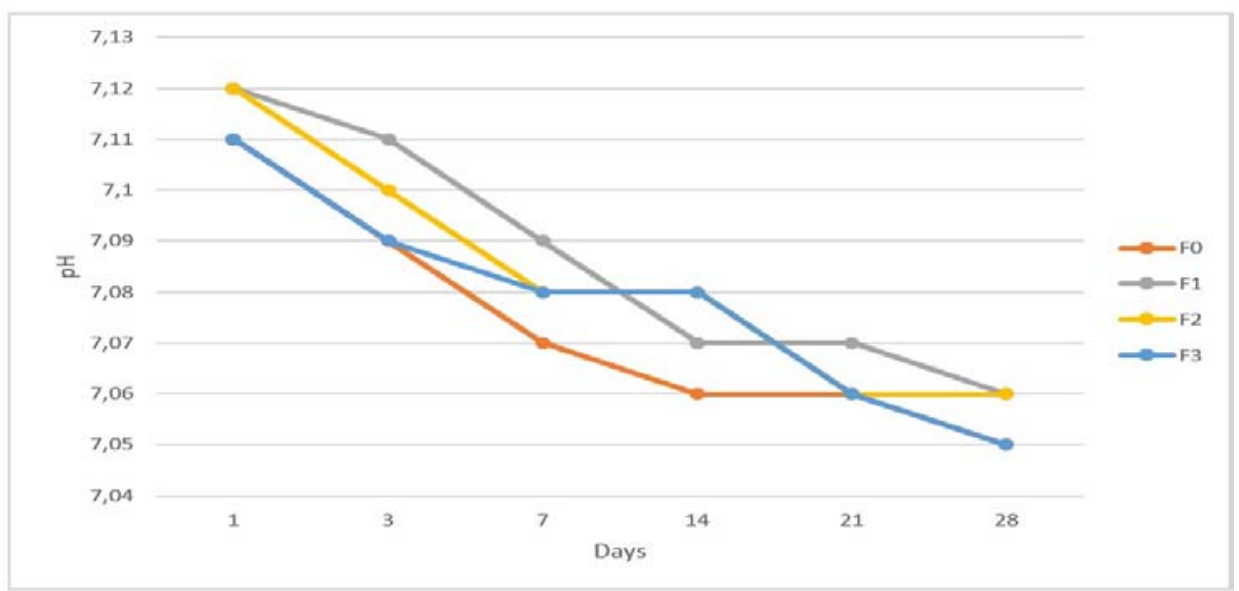

Fig. 1: The pH changes of $0.5 \%$ chloramphenicol eye drops over storage time

\section{Sterility test}

The sterility of the eye drops must be maintained throughout the usage period [30]. Therefore, they are formulated with preservative to extend the use duration. Some severe eye infections have been reported to occur after the use of multidose eye drops due to pathogen contamination of multidose eye drops, which can be sourced from several things such as air contamination or touching the eye drop bottle dropper with fingers, eyelids, or eyelashes during dripping [31-33]. The occurrence of contaminated eye drops may lead to product degradation which decreasing the effectiveness of the product [7]. The longer the time of eye drops use, contact frequency of the eye drops with ocular surfaces will be mounted and thus the potency of getting contamination will be increased [17]. Therefore, formulating preservatives in eye drops is very useful for preventing microbial contamination during the eye drops use and storage. However, another study revealed that the products were found to be contaminated for $11 \%$, even though they were formulated with benzalkonium chloride or thimerosal as preservatives $[7,17]$. These finding indicated that the determination of the most effective preservative must be studied to ensure the sterility of the eye drops and the compatibility of the preservative with the active agent and others substances in the formula, by observing their antibacterial efficacy against the $E$. coli.

The sterility of the eye drops products was consisted of fertility, effectiveness and sterility test. The media used in the sterility test have checked for its fertility to ensure that the media was capable of supporting the microorganism growth and the resulted of medium turbidity demonstrated the growth of B. subtilis and C. albicans. For the sterility of the used media, the incubated media showed no microorganism was growth. Thus, the media can be used to validate the sterility of the prepared eye drops containing different preservatives. As the result of eye drops sterility test, all formulas of the eye drops preparation were confirmed as sterile preparations during the storage period, as well as a blank formula without preservative content. The result illustrated that the sterilization process was running properly, but it cannot be described the preservative efficacy, due to the occurrence of eye drops blank sterility.

\section{Efficacy test}

The used of preservatives in eye drop preparation was aimed to prevent microbial contamination during use and storage, which may occur and cause product degradation or ocular infection [7]. Thus, eye drops as one of the sterile products that must be protected to maintain the product quality against the opportunistic contamination by selecting the most appropriate and effective preservative. Preservatives concentration in eye drops is limited due to their side effects such as irritate the eyes and damage the eyeball surface [34]. In this study, the preservative concentration was chosen in the range of its recommended concentration for ophtalmic product. Benzalkonium chloride is a common used preservative in eye drops at a concentration range from $0.004 \%$ to $0.01 \%$ [35]. The thimerosal preservative in ophthalmic products at typical 
concentrations ranges of $0.001 \%$ to $0.01 \%$ (FDA). Meanwhile, benzyl alcohol is a preservative used at concentrations up to $2.0 \% \mathrm{v} / \mathrm{v}$, but the frequently concentration used is $1 \% \mathrm{v} / \mathrm{v}$ [36-40]. But, in the other hand, the role of preservative to hinder eye drops contamination, has been controversial [41]. In fact, the eye drops's shelf-life is determined by the preservatives themselves, rather than the main components. Expired eyedrop mean loss of preservative potency to protect the eye drops from microbial contamination [42]. Therefore, preservatives must fulfill certain requirement such as; compatibility with other components in the eye drops, non-toxic and must be efficient during the entire of use.

The preservative employed in chloramphenicol eye-drops challenged with E. coli and produced strong antibacterial activity, performed in table 3 and illustrated in fig. 2. This showed the synergistic effect between chloramphenicol and the preservative against $E$. coli. The most effective antibacterial formula was shown by formula 2 which contained thimerosal as the preservative. In this study, the addition of the preservatives in all eye drops formula can improve the antibacterial effect of chloramphenicol, compared with the F0 as the blank formula containing the same concentration of chloramphenicol as others formula, but did not contain any preservatives at all. These data informed that the presence of the added preservatives improved the antibacterial efficacy of choloramphenicol in eye drop preparations. Moreover, the improve efficacy revealed the compatibility of the preservatives with the chloramphenicol as the main ingredients of the eye drops.

Table 3: Inhibition effect of preservatives in $0.5 \%$ chloramphenicol eye drops

\begin{tabular}{llllll}
\hline Formula & \multicolumn{6}{l}{ Diameter of inhibition (mm) during the storage periode (day) } \\
\cline { 2 - 6 } & $\mathbf{1}$ & $\mathbf{3}$ & $\mathbf{5}$ & $\mathbf{7}$ & $\mathbf{1 4}$ \\
\hline F0 & $36.25 \pm 0.002$ & $34.55 \pm 0.002$ & $29.5 \pm 0.01$ & $26.25 \pm 0.002$ & $22.55 \pm 0.002$ \\
F1 & $36.35 \pm 0.002$ & $35.20 \pm 0.000$ & $32.75 \pm 0.002$ & $28.45 \pm 0.002$ & $26.30 \pm 0.000$ \\
F2 & $36.40 \pm 0.000$ & $35.55 \pm 0.002$ & $33.40 \pm 0.01$ & $31.06 \pm 0.002$ & $27.65 \pm 0.002$ \\
F3 & $36.35 \pm 0.002$ & $35.25 \pm 0.002$ & $32.85 \pm 0.002$ & $30.80 \pm 0.000$ & $26.80 \pm 0.000$ \\
\hline
\end{tabular}

Notes: Diameter of inhibition (mean \pm SD) and each number of experiment replication $=3$

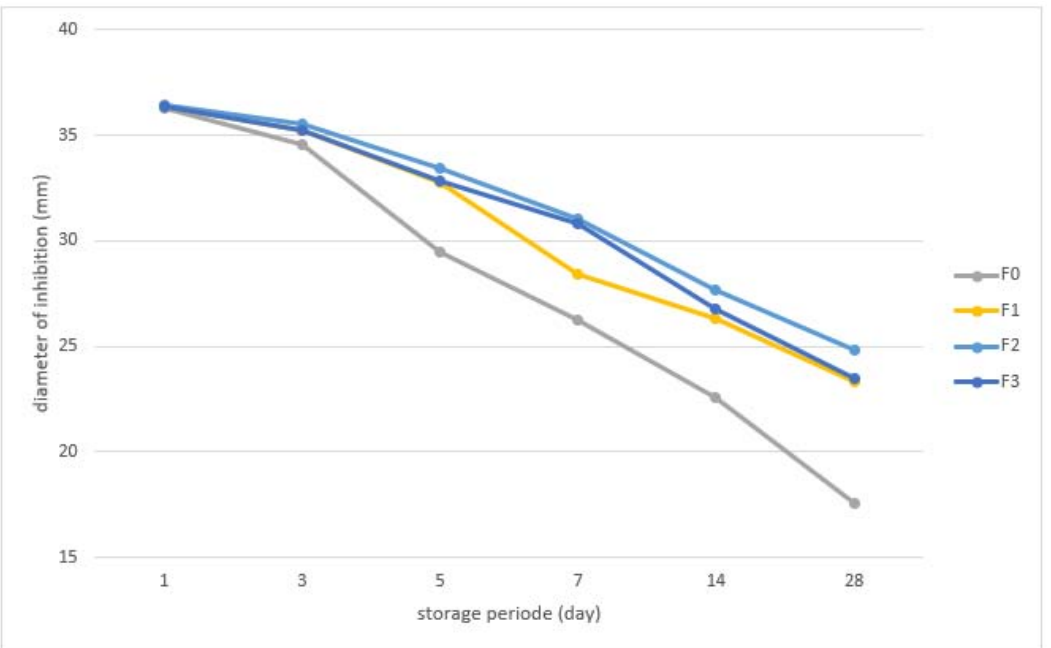

Fig. 2: Antibacterial efficacy of $0.5 \%$ chloramphenicol eye drops with different preservative

Based on fig. 2, it was clearly justified that F2 with thimerosal as the preservative, showed the highest efficacy as antibacterial against $E$. coli. The solubility and stability of chloramphenicol was important to be enhanced and maintained to develop an effective eye drops with antibacterial mechanism. It was reported that the chloramphenicol solubility is only $0.25 \%$ in purified water. Likewise, when the eye drops $\mathrm{pH}$ is raised to 8.6 , then, its solubility achieves to $1 \%$ and may reduce its stability and antibacterial activity [43]. The adjustment $\mathrm{pH}$ of chloramphenicol eye drops used boric acid was one of the efforts to raise the required solubility of chloramphenicol. Not only to the chloramphenicol, the $\mathrm{pH}$ values also have an essential impact to the preservative's action. $\mathrm{pH}$ can influence the rate of microbial growth of and the interaction between preservative with microbial cell wall components [44, 45]. Generally, the optimal $\mathrm{pH}$ for microbial growth is in the range of 6-8. Outside this $\mathrm{pH}$ range, then, the microbial growth rate may significantly decline. The $\mathrm{pH}$ of the product may describe the intrinsic $\mathrm{pH}$ of the active components, or the product may need $\mathrm{pH}$ alteration to improve product solubility, stability, palatability or optimal microbial effectiveness. Thimerosal is stable in neutral $\mathrm{pH}$ or weak alkaline, the benzalkonium chloride in the range of 4-10 and benzyl alcohol is at $<\mathrm{pH} 5$ [46-48]. Therefore the antibacterial of F3 produced the smallest antibacterial activity against $E$. coli, due to the $\mathrm{pH}$ of $\mathrm{F} 3$ was lower than the optimum $\mathrm{pH}$ for benzyl alcohol action. The stability, preservatives and sterility of ophthalmic preparations are more stressed, rather than tonicity [43]. Thimerosal is a common preservative for eye drops preparation. However, thimerosal was found to be harmful due to its organic-mercury (Hg) content in thimerosal. But, the United States Centers for Disease Control and Prevention claimed that thimerosal is safe preservative and not related with the occurrence of autism rates in children due to the use of thimerosal-containing vaccines [19]. Thus, this preservative can be chosen as the effective preservative formulated in eye drops preparation containing $0.5 \%$ chloramphenicol.

Beside to the $\mathrm{pH}$, the length of the storage time gave different effects on inhibition diameter in each formula. In each formula, as storage days increasing, the antibacterial efficacy tends to be reduced. During the storage period, all formulas had the decreasing in antibacterial potency and it might be due to the change in the $\mathrm{pH}$ of each formula. The percentage decrease in inhibition diameter occurred during the storage period of each formula, counted from the early storage to the final storage period was as follows: F0 (51.58\%), F1 (35.76\%), F2 (31.86\%), and F3 (35.35\%). Based on those decreasing values, it can be concluded that the existence of preservatives have an important contribution in stabilizing the eye drop product, even the product contain antibiotics. The differences values in inhibition diameter were significantly influenced by the type of preservatives. It can be seen that 
in the absence of preservatives, the antibacterial potency of chloramphenicol decreased sharply over the storage time. The type of preservative also determined the efficacy of these chloramphenicol eye drops. The best formula for their stability in antibacterial potency was produced by $\mathrm{F} 2$ which used $0.01 \%$ thimerosal as its preservative, meanwhile the formula containing benzalkonium chloride (F1) had better antibacterial efficacy than that of containining benzyl alcohol (F3). There was a significant difference in the effect of the formula eye drops with respect to storage time. Based on statistical analysis, the Fcount value $(6136,308)$ was greater than the F-table $(3.0088)$, thus, Ho was rejected. It demonstrated that there was a significant difference of the different formulas on the inhibitory diameter. Similarly, for the storage time factor, the F-count value $(43762,123)$ was greater than the F-table $(2,6207)$, Ho was rejected. Therefore, there was a significant difference in the diameter of inhibition. In addition, the interaction between those treatment factors, with a Fcount-value $(597,385)$ greater than F-table $(2.1077)$ so that Ho was rejected. This revealed that there was a significant effect on the inhibitory diameters if the two levels of the factors were combined. Statistically, it can be concluded that different formulas give different inhibitory diameters (effectiveness). Based on the Newman-Keuls range test it was known that there were differences in the influence of the preparation formula, storage time and the interaction of the preparation formula with a significant storage time in all chloramphenicol eye drops.

\section{CONCLUSION}

In conclusion, all the eye drops formulas containing different preservatives including that of without preservative (F0) were physically stable during the storage period and the $\mathrm{pH}$ of all formulas have complied with the requirements for the compatibility with eye physiology. However, among the used preservatives, the chloramphenicol eye drop formula using $1 \%$ benzyl alcohol as the preservative shown the highest decreasing in $\mathrm{pH}$ and diameter of inhibition over the storage period. However, the eye drop formula without preservative demonstrated the worst stability both on physical and microbiological observation. Meanwhile, the formula that contained $0.01 \%$ thimerosal exhibited better stability than that of $0.01 \%$ benzalkonium chloride. Thus, it can be concluded that efficacy of $0.5 \%$ chloramphenicol eye drop was significantly influenced by the presence and the type of preservatives. From this present study, $0.01 \%$ thimerosal can be recommended as an effective preservative to be formulated in the formula of $0.5 \%$ chloramphenicol eye drop with respect to its product sterility and its antibacterial efficacy to inhibit $E$. coli.

\section{FUNDING}

Nil

\section{AUTHORS CONTRIBUTIONS}

All the authors have contributed equally.

\section{CONFLICT OF INTERESTS}

\section{Declared none}

\section{REFERENCES}

1. Beal C, Giordano B. Clinical evaluation of red eyes in pediatric patients. J Pediatr Health Care 2016;30:506-14.

2. Azari AA, Barney NP. Conjunctivitis: a systematic review of diagnosis and treatment. JAMA 2013;310:1721-9.

3. Epling J. Bacterial conjunctivitis. Br Med J Clin Evid 2012;2:1-21.

4. Limberg MB. A review of bacterial keratitis and bacterial conjunctivitis. Am J Ophthalmol 1991;112:2S-9S.

5. Thadani SM, Foster CS. Treatment of ocular inflammation in children. Pediatr Drugs 2004;6:289-301.

6. Høvding G. Acute bacterial conjunctivitis. Acta Ophthalmol 2008;86:5-17.

7. Feghhi M, Mahmoudabadis AZ, Mehdinejad M. Evaluation of fungal and bacterial contaminations of patient-used ocular drops. Med Mycol 2008;46:17-21.

8. Patel PB, Diaz MC, Bennett JE, Attia MW. Clinical features of bacterial conjunctivitis in children. Acad Emerg Med 2007;14:1-5.

9. Rietveld RP, Ter Riet G, Bindels PJ, Sloos JH, Van Weert HC. Predicting bacterial cause in infectious conjunctivitis: cohort study on informativeness of combinations of signs and symptoms. Br Med J 2004;329:206-10.

10. Sheikh A, Hurwitz B. Antibiotics versus placebo for acute bacterial conjunctivitis. Cochrane Database Syst Rev 2006;4:CD001211.

11. Peneva PT. Non-steroidal anti-inflammatory drugs for topical ophthalmic administration: contemporary trends. Int J Pharm Pharm Sci 2015;7:13-9.

12. Buckley SA. Survey of patients taking topical medication at their first presentation to eye casualty. $\mathrm{Br}$ Med J 1990;300:1497-8.

13. Kirkness CM, Seal DV, Hay J. Topical chloramphenicol: use or abuse? Eye 1995;9:7-8.

14. Hall AV, Das SS, Tabaqchali S. Is it time to stop using chloramphenicol on the eye? Risk is low in short courses [Letter]. Br Med J 1995;311:450-1.

15. Sinclair NM, Leigh DA. A comparison of fusidic acid viscous eye drops and chloramphenicol eye ointment in acute conjunctivitis. Ther Res 1988;44:468-74.

16. WHO. Blindness and vision impairment prevention. WHO, Geneva; 2020.

17. Tsegaw A, Abula T, Assefa Y. Bacterial contamination of multidose eye drops at ophthalmology department, University of Gondar, Northwest Ethiopia. Middle East Afr J Ophthalmol 2017;24:81-6.

18. Taşli H, Coşar G. Microbial contamination of eye drops. Cent Eur J Public Health 2001;9:162-4.

19. Hooker B, Kern J, Geier D, Haley B, Sykes L, King P, et al. Methodological issues and evidence of malfeasance in research purporting to show thimerosal in vaccines is safe. BioMed Res Int 2014;1-8. https://doi.org/10.1155/2014/247218

20. Baird RM. Guide to microbiological control in pharmaceuticals. CRC Press, New York; 2007.

21. Noecker R. Effects of common ophthalmic preservatives on ocular health. R Adv Ther 2001;18:205-15.

22. Klein M, Millwood EG. On the sterility of eye ointments. Br J Ophthal 1964;48:285-7.

23. Yi Sheng C, Chiou Feng L, Chao Liang W, Pao Ying K, Fong Sen $\mathrm{W}$, Chi Chang S, et al. Mechanisms underlying benzyl alcohol cytotoxicity (triamcinolone acetonide preservative) in human retinal pigment epithelial cells. Invest Ophth Vis Sci 2011;52:4214-22.

24. Abdassah M, Kusuma SAF. Comparison of thimerosal effectiveness in the formulation of eye drops containing neomycin sulfate and chloramphenicol. Int J Appl Pharm 2019;11:130-5

25. Kusuma SAF, Hargono Y, Winarno H. Betalactamase enzyme role in minimizing false-positive result of cefotaxime injection end-product sterility. J Pharm Sci Res 2018;10:1036-40.

26. Sudjana MA. Metode statistika. $8^{\text {th }}$ ed. Penerbit Tarsito, Bandung; 2002.

27. Shih IK. Photodegradation products of chloramphenicol in aqueous solution. J Pharm Sci 1971;60:1889-90.

28. Jitendra, Sharma PK, Banik A, Dixit S. A new trend: ocular drug delivery system. Int J Pharm Sci 2011;2:1-25.

29. Lukas S. Formulasi Steril. Penerbit ANDI, Yogyakarta; 2006

30. British Pharmacopoeia. Efficacy of antimicrobial preservation. Vol. IV. Appendix XVI C A367-A369. The Stationery Office, London; 2007.

31. Kallings L, Rigertz O, Silverstolpe I. Microbial contamination of medical preparations. Acta Pharm Sue 1966;3:199-213.

32. Furrer P, Mayer JM, Gurny R. Ocular tolerance of preservatives and alternatives. Eur J Pharm Biopharm 2002;53:263-80.

33. Rahman MQ Tejwani D, Wilson JA, Butcher I, Ramaesh K. Microbia contamination of preservative free eye drops in multiple application containers. Br J Ophthalmol 2006;90:139-41.

34. Bartlett JD, Siret JD. Clinical ocular pharmacologi. $4^{\text {th }}$ ed. Butterwort Heinemann; 2001.

35. Nelson L, Goldfrank L. Goldfrank's toxicologic emergencies. $9^{\text {th }}$ ed. McGraw-Hill Medical; 2011.

36. Croshaw B. Preservatives for cosmetics and toiletries. J Soc Cosmet Chem 1977;28:3-16.

37. Karabit MS, Juneskans OT, Lundgren P. Studies on the evaluation of preservative efficacy II: the determination of 
antimicrobial characteristics of benzyl alcohol. J Clin Hosp Pharm 1986;11:281-9.

38. Shah AK, Simons KJ, Briggs CJ. Physical, chemical, and bioavailability studies of parenteral diazepam formulations containing propylene glycol and polyethylene glycol 400. Drug Dev Ind Pharm 1991;17:1635-54.

39. Wallhausser KH. Benzyl alcohol. Kabara JJ. ed. Cosmetic and drug preservation principles and practice. Marcel Dekker, New York; 1984.

40. Meyer BK, Ni A, Hu B, Shi L. Antimicrobial preservative use in parenteral products: past and present. J Pharm Sci 2007;96:3155-67.

41. Saisyo A, Oie S, Kimura K, Sonoda KH, Furukawa H. Microbia contamination of in-use ophthalmic preparations and its prevention. Bull Yamaguchi Med Sch 2016;63:17-24.

42. Bachewar NP, Deshmukh D, Choudhari SR, Joshi RS. Evaluation of used eye drop containers for microbial contamination in outpatient department of tertiary care teaching hospital. Int J Basic Clin Pharmacol 2018;7:895-9.
43. Jithan V, Mohan CK, Vimaladevi M. Development and evaluation of a chloramphenicol hypertonic ophthalmic solution. Indian J Pharm Sci 2008;70:66-70.

44. Fassihi RA. Preservation of medicines against microbial contamination. In: SA Block. Ed. Disinfection Sterilization and Preservation. $4^{\text {th }}$ Ed. Lea and Febiger; 1991.

45. Hugo WB, Russell AD. Pharmaceutical microbiology. $6^{\text {th }} \mathrm{Ed}$. Blackwell Science; 1998.

46. Van Horn DL, Edelhauser HF, Prodanovich G, Eiferman R, Pederson HF. Effect of the ophthalmic preservative thimerosal on rabbit and human corneal endothelium. Invest Ophthalmol Vis Sci 1977;16:273-80.

47. Kibbe AH. Benzalkonium chloride monograph. In: Rowe RC, Sheskey PJ, Weller PJ. Handbook of Pharmaceutical Excipients. $5^{\text {th }}$ ed. Pharmaceutical Press; 2006.

48. Cahill E. Benzyl alcohol monograph. In: Rowe RC, Sheskey PJ Weller PJ. Handbook of Pharmaceutical Excipients. $5^{\text {th }}$ ed. Pharmaceutical Press; 2006. 